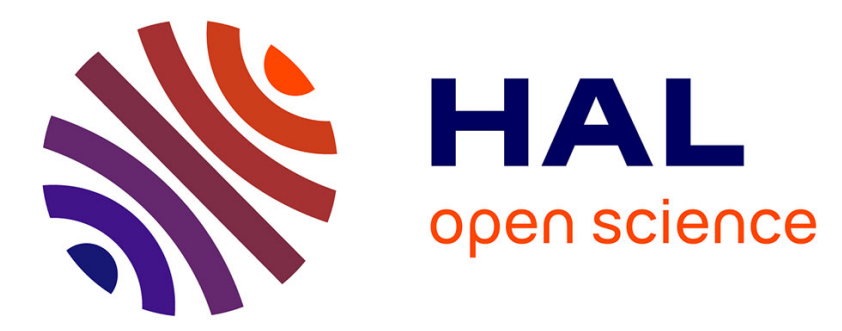

\title{
Characteristics of chlorites in seismogenic fault zones: the Taiwan Chelungpu Fault Drilling Project (TCDP) core sample
}

Y. Hashimoto, O. Tadai, M. Tanimizu, W. Tanikawa, T. Hirono, W. Lin, T. Mishima, M. Sakaguchi, W. Soh, S. R. Song, et al.

\section{To cite this version:}

Y. Hashimoto, O. Tadai, M. Tanimizu, W. Tanikawa, T. Hirono, et al.. Characteristics of chlorites in seismogenic fault zones: the Taiwan Chelungpu Fault Drilling Project (TCDP) core sample. eEarth, 2008, 3 (1), pp.1-6. hal-00298237

\section{HAL Id: hal-00298237 \\ https://hal.science/hal-00298237}

Submitted on 29 Feb 2008

HAL is a multi-disciplinary open access archive for the deposit and dissemination of scientific research documents, whether they are published or not. The documents may come from teaching and research institutions in France or abroad, or from public or private research centers.
L'archive ouverte pluridisciplinaire HAL, est destinée au dépôt et à la diffusion de documents scientifiques de niveau recherche, publiés ou non, émanant des établissements d'enseignement et de recherche français ou étrangers, des laboratoires publics ou privés. 


\section{Characteristics of chlorites in seismogenic fault zones: the Taiwan Chelungpu Fault Drilling Project (TCDP) core sample}

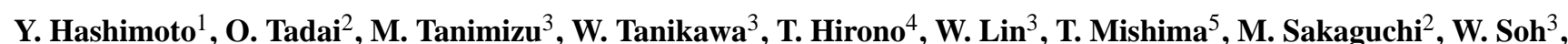

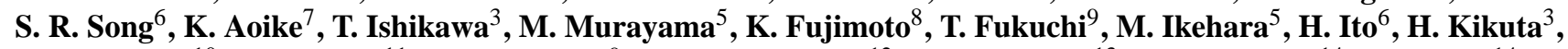
M. Kinoshita ${ }^{10}$, K. Masuda ${ }^{11}$, T. Matsubara ${ }^{9}$, O. Matsubayashi ${ }^{12}$, K. Mizoguchi ${ }^{13}$, N. Nakamura ${ }^{14}$, K. Otsuki ${ }^{14}$, T. Shimamoto ${ }^{15}$, H. Sone ${ }^{16}$, and M. Takahashi ${ }^{11}$

${ }^{1}$ Department of Natural Environmental Science, Kochi University, Kochi, Japan

${ }^{2}$ Marine Works Japan Ltd., Nankoku, Japan

${ }^{3}$ Kochi Institute for Core Sample Research, Japan Agency for Marine-Earth Science and Technology, Nankoku, Japan

${ }^{4}$ Department of Earth and Space Science, Graduate School of Science, Osaka University, Toyonaka, Japan

${ }^{5}$ Center for Advanced Marine Core Research, Kochi University, Nankoku, Japan

${ }^{6}$ Department of Geosciences, National Taiwan University, Taipei, Taiwan

${ }^{7}$ Center for Deep Earth Exploration, Japan Agency for Marine-Earth Science and Technology, Yokohama, Japan

${ }^{8}$ Faculty of Education, Tokyo Gakugei University, Koganei, Japan

${ }^{9}$ Department of Earth Sciences, Graduate School of Science \& Engineering, Yamaguchi University, Yamaguchi, Japan

${ }^{10}$ Institute for Research on Earth Evolution, Japan Agency for Marine-Earth Science and Technology, Yokosuka, Japan

${ }^{11}$ Institute of Geology and Geoinformation, National Institute of Advanced Industrial Science and Technology, Tsukuba, Japan

${ }^{12}$ Institute for Geo-Resources and Environment, National Institute of Advanced Industrial Science and Technology, Tsukuba, Japan

${ }^{13}$ Earthquake Research Department, National Research Institute for Earth Science and Disaster Prevention, Tsukuba, Japan

${ }^{14}$ Department of Geoenvironmental Science, Graduate School of Science, Tohoku University, Sendai, Japan

${ }^{15}$ Department of Earth and Planetary Systems Science, Hiroshima University, Japan

${ }^{16}$ Department of Geophysics, School of Earth Sciences, Stanford University, Stanford, CA, USA

Received: 21 May 2007 - Published in eEarth Discuss.: 2 July 2007

Revised: 16 January 2008 - Accepted: 21 January 2008 - Published: 29 February 2008

\begin{abstract}
The iron content and the asymmetry of iron and magnesium ions in chlorites are examined for the Chelungpu Fault in Taiwan, which is a seismogenic fault. The samples are collected from the cores drilled for the Taiwan Chelungpu Fault Drilling Project (TCDP, borehole B). Three fault zones are recognized as candidates for the source of seismogenic materials. The fault zones are composed of fractured-damaged rocks, breccia, gray gouge, black gouge, and black material. Chlorite from each type of rock was analyzed by using X-ray diffraction (XRD). The iron content and asymmetry of the iron and magnesium ions in the
\end{abstract}

Correspondence to: Y. Hashimoto

(hassy@cc.kochi-u.ac.jp) chlorites were estimated from the XRD peak ratios. The hydroxide and silicate layers of chlorite in the black gouge and black material have low iron contents. Many studies have suggested that a temperature rise occurred at the fault zones. In addition, the temperature rise can result in the production of iron oxides such as magnetite or maghemite, as reported by other studies. However, the temperature rise cannot explain the low value of iron content in the chlorites. Another reason for the low value of iron content is the variation in the $\mathrm{pH}$ of the fluid, which can be controlled by radical reactions. Therefore, on the basis of chlorite characteristics, the reactions at the seismogenic fault are due not only to the thermal decomposition resulting from the temperature rise and but also to rock-fluid interactions. 


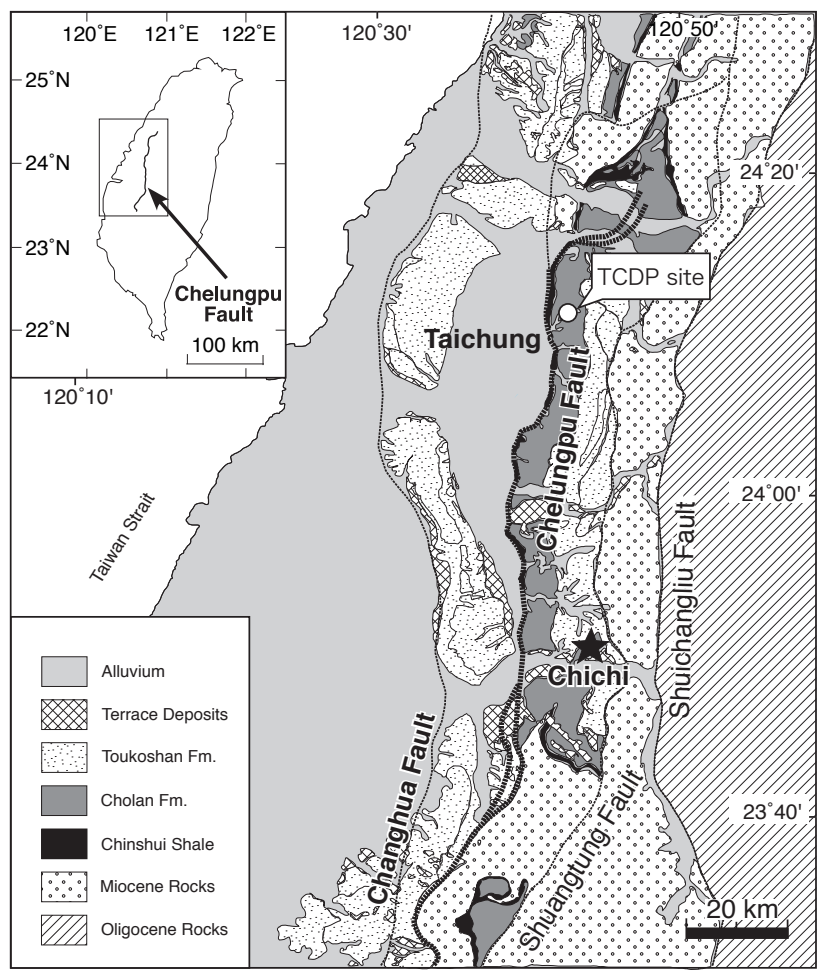

Fig. 1. A geological map of central Taiwan. Location of the TCDP site is shown.

\section{Introduction}

The formation of clay minerals within gouges is strongly related to fault activities because gouges are common products of shallow faulting (e.g. Sibson, 1977) and clay minerals are dominant in gouges. Because the clay-rich gouges are often observed in natural fault zones, clay minerals are important to understand fault processes. However, the mechanical processes or reactions resulting in the formation of clay minerals along fault zones is poorly understood because of the complexity of the interaction between clay formation and faulting (Vrolijik and van der Pluijm, 1999).

In this study, we focused on the characteristics of clay minerals in seismogenic fault rocks. In particular, the characteristics of chlorite were analyzed because chlorite can be classified on the basis of the detailed composition of iron and magnesium from X-ray diffraction analysis (Moore and Reynolds, 1989). The iron and magnesium composition in chlorite can be related to the thermal condition (Ohta and Yamaji, 1988; Vidal et al., 2006), rock-fluid interaction (e.g. Ross, 1969; Malmstrom et al., 1996) or chemical variation in source materials.

The analyzed samples are from the Chelungpu Fault in Taiwan. The fault is located at the western side of Taiwan forming a fold and thrust belt with other thrust faults such as Changhua Fault or Shuagtung Fault (Fig. 1). The Chelungpu fault was activated during the Chi-Chi Earthquake ( $\mathrm{Mw}=7.6)$ on 21 September 1999 (e.g. Ma et al., 2000). On the basis of a high-resolution map of the displacement on the fault surface, an area with a large displacement (asperity) is located in the shallows in the northern part of the fault (e.g. Ma et al., 2000). The Taiwan Chelungpu Fault Drilling Project (TCDP) was conducted to investigate the fault zone to a depth of approximately $1 \mathrm{~km}$ at the northern site of the Chelungpu fault (Fig. 1). In this study, the Hole B core samples recovered from the depth range of $948.42 \mathrm{~m}$ to $1352.60 \mathrm{~m}$ are analyzed.

In the northern part of the Chelungpu fault, the absence of high-frequency radiations has been reported. The mechanism for the generation of low-frequency radiations is suggested to be hydrodynamic lubrication (e.g. Ma et al., 2000; Kano, 2006). On the other hands, the frictional heating at the time of seismicity is also suggested by former studies of the same fault (Kano et al., 2006; Hirono et al., 2006b; Mishima et al., 2006). Therefore, both fluid-rock interaction and frictional heating are expected to control the clay composition along the fault. We use chlorite to examine the issue because characteristics of chlorite can provide thermal and chemical conditions along the fault.

\section{Occurrences of fault rocks}

From the drilled core in borehole B, three fault zones have been identified with thick gouges as the candidates for the source of the seismogenic material; these fault zones are located at $1136 \mathrm{~m}, 1194 \mathrm{~m}$, and $1243 \mathrm{~m}$ in depth (Hirono et al., 2006a) and are named FZB 1136, FZB 1194, and FZB 1243, respectively. In the borehole A which is located at $40 \mathrm{~m}$ apart from the borehole $\mathrm{B}$, three fault zones were also observed as FZA 1111, FZA 1222 and FZA 1253 (e.g. Ma et al., 2006). Those fault zones must be corresponding to the fault zones in borehole B. All the fault zones are located in the Chinsui shale (Fig. 1), which is mainly composed of black shales with minor sandstones. Schematic images of the fault zones are presented in Fig. 2. The rock types are divided into two-host rocks and fault rocks. The fault rocks are classified into five types: Fractured-damaged rock, breccia, gray gouge, black gouge, and black material (Fig. 2). The black material is an ultra-fine-grained material with small fragments (less than $100 \mu \mathrm{m})$ as reported by Hirono et al. (2006a). Clay minerals are formed in the gouges representing strong preferred orientation texture parallel to the fault planes in microscopic scale, which indicates that the clay mineral formation might be related to faulting. In the host rock, such kind of preferred oriented clay minerals are not observed. The distributions of the fault rocks in each fault zone can be summarized as follows:

FZB 1136: Approximately $1.23 \mathrm{~m}$ of thick breccia zone is located above the gouges. The gouges are composed of gray and black gouges. There is no black material within the gouge zone in this fault zone. A relatively thin (approximately $30 \mathrm{~cm}$ ) breccia zone is located below the gouge 


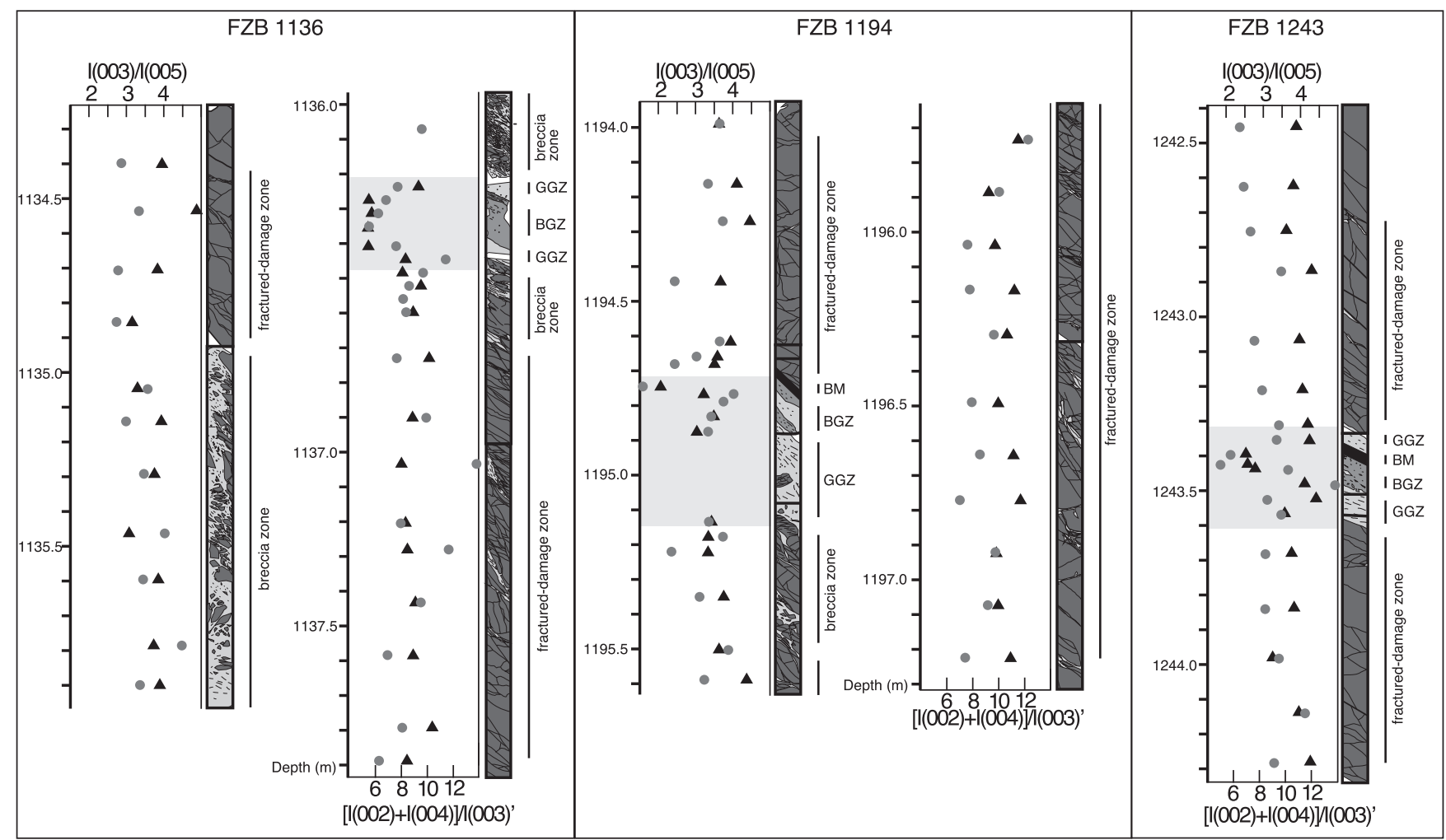

Fig. 2. Schematic images of the fault zones and distributions of $\mathrm{I}(003) / \mathrm{I}(005)$ (indicative of the symmetry of Fe distribution, gray circles) and $[\mathrm{I}(002)+\mathrm{I}(004)] / \mathrm{I}(003)^{\prime}$ (inidicative of the total number of Fe atoms, black triangles). Shaded areas indicate the gouge zone in each fault zone.

zone. Two fractured-damaged zones (up to $1.2 \mathrm{~m}$ ) are located above and below each breccia zone (Fig. 2).

FZB 1194: There is no breccia zone above the gouge zone. Instead, a 2-cm layer of black material exists at the top of the fault gouge zone. Below the black material, black gouge and gray gouge are present. A relatively thin breccia zone is identified below the gouge zone. The fractured-damaged zone is also located outside the fault core.

FZB 1243: There is no breccia zone both above and below the gouge zone. The fractured-damaged zones are located outside the gouge zone. Gray gouge zones are situated in the upper and lower parts of the gouge zone. Black material exists below the upper gray gouge. Below the black material, there is a black gouge zone about $10 \mathrm{~cm}$ in thickness (Fig. 2).

The fault rocks analyzed in this study must be formed by historical earthquake cycles. So, the characteristics of chlorite might contain the historical processes.

\section{XRD analysis}

We analyzed the clay minerals using an X-ray diffractometer (XRD) (PANalytical X'PertPRO MPD). The oriented samples were prepared using $<1.4 \mu \mathrm{m}$ grains. The XRD analysis was conducted under the following conditions: $45 \mathrm{kV}$,
$40 \mathrm{~mA}$ of $\mathrm{Cu} \mathrm{k} \alpha$ radiation, step size of $0.01^{\circ} \mathrm{C}$, and the range of $2 \theta$ was from $3^{\circ}$ to $40^{\circ}$. Random oriented samples were also analyzed by the XRD analysis for bulk rock samples.

The result of the XRD analysis reveals that most of the samples contain smectite, illite, kaolinite, and chlorite. Figure 3 depicts examples of the intensity profile of the XRD analysis in this study. Note that the intensities of chlorite peaks, denoted by the ratios 002, 003, 004, and 005, are different in host rocks and black materials (Fig. 3). The numbers of samples analyzed are 36, 35, and 24 for FZB 1136, FZB 1194, and FZB 1243, respectively.

\section{The characteristics of chlorite}

Chlorite is identified in all the analyzed samples. The chlorite in the study is Fe-Mg chlorite (Clinochlore-1MIIb, ferroan) in both the host rock and fault rocks on the basis of the buld rock analysis. Chlorite is composed of a silicate layer and hydroxide layer with three sites for positive ions in both the layers. We have estimated the iron and magnesium contents in chlorite from XRD charts following the method proposed by Moore and Reynolds (1989). They use also oriented samples for clay mineral determination but procedure proposed by Brown and Brindley (1980) has been calculated 


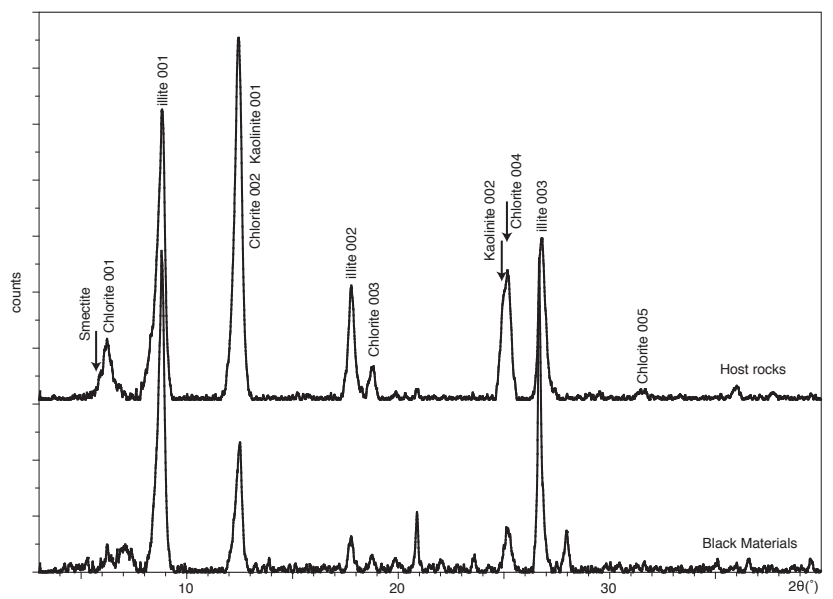

Fig. 3. Examples of the intensity profiles of XRD charts for host rock and black material. Chlorite peaks are indicated.

for random oriented samples. I(003)/I(005) gives the symmetry of Fe Distribution (D value in Moore and Reynolds) and $[\mathrm{I}(002)+\mathrm{I}(004)] / \mathrm{I}(003)^{\prime}$ gives the number of Fe atoms in six octahedral sites ( $\mathrm{Y}$ value in Moore and Reynolds). Here, $\mathrm{I}(003)^{\prime}$ is corrected by using the following equation (Brown and Brindley, 1980):

$\mathrm{I}(003)^{\prime}=\frac{\mathrm{I}(003)(114)^{2}}{(114-12.1 \mathrm{D})^{2}}$

The NEWMOD calculation of chlorite provides the reference frame in the configuration described above for iron and magnesium from 0 to 3 at intervals of 0.5 in the silicate and hydroxide layers (the total number of patterns is 49), respectively. The results of the NEWMOD calculations are shown in Fig. 4 in the $\mathrm{I}(003) / \mathrm{I}(005)$ vs. $[\mathrm{I}(002)+\mathrm{I}(004)] / \mathrm{I}(003)^{\prime}$ space as dotted lines.

The peak intensities are obtained using MacDiff 4.2.5. Kaolinite is also identified in almost all the samples in this study. Therefore, I(002) and I(004) for chlorite are carefully obtained using the fitting operation of MacDiff 4.2.5. Figure 2 represents the distribution of the parameters with the depth. Figure 4 shows the differences in the iron content and asymmetry of ions between the rock types in each fault zone using the NEWMOD reference frame indicating the amount of iron in each layer.

In a broad sense, the iron content in host rocks, fractureddamaged rocks, breccia, and most of the gray gouge is constant. There is approximately $2.5-3$ of iron in the hydroxide layer and 2-2.5 of iron in the silicate layer (Fig. 4), which is very high iron content. For black gouge and some gray gouge, a relatively low iron content is found (Fig. 4). In particular, the trend is very clear in FZB 1136. In FZB 1194, the change in iron content between black gouge and host rocks is smaller than that in FZB 1136. The differences in iron contents between black gouge and host rocks in FZB 1243 is not clear because of the small number of samples. Although
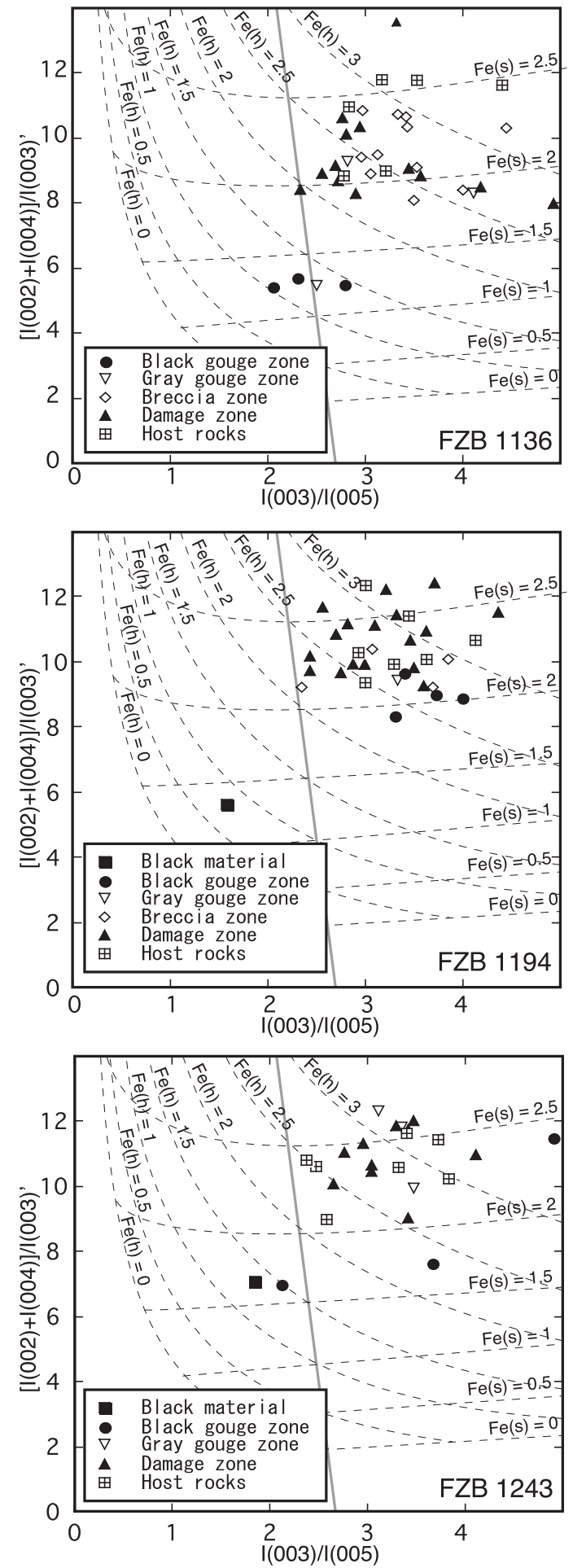

Fig. 4. Characteristics of chlorite in each fault rock expressed in $\mathrm{I}(003) / \mathrm{I}(005)$ vs. $[\mathrm{I}(002)+\mathrm{I}(004)] / \mathrm{I}(003)^{\prime}$ space. Dotted lines indicate the reference frame calculated from NEWMOD. The amount of iron in the hydroxide layers is denoted by $\mathrm{Fe}(\mathrm{h})$ and in the silicate layers by $\mathrm{Fe}(\mathrm{s})$. The gray line indicates the zero symmetry $(\mathrm{Fe}=\mathrm{Mg}$ in the two layers). 
the number of samples is limited, the black materials have a fairly low iron content when compared to that of the other types of rocks both in FZB 1194 and FZB 1243 (Fig. 4). The distribution of the parameters also represents lower values of the parameters at the fault core (Fig. 2), which means that lower values of the iron contents are observed at the faults.

\section{Discussion and conclusion}

The iron content in chlorite is controlled by the temperature (Ohta and Yajima, 1988; Vidal et al., 2006) or the $\mathrm{pH}$ of the fluid (e.g. Ross, 1969; Malmstrom et al., 1996). It is also possible that the source material can control the iron content in chlorite. However, the Chinsui shale is very homogeneous as shown by the constant iron and magnesium contents in host rocks (Fig. 4). Therefore, the source material also was probably homogeneous and is not the cause of the low value of iron content in the gouge.

Thermal anomalies have been reported at the FZA 1111 fault zone in the borehole $\mathrm{A}$, which can be corresponds to the FZB 1136 in borehole B, on the basis of borehole logging (Kano et al., 2006). They assumed that the thermal anomaly was caused by frictional heating. They estimated a low frictional coefficient on the basis of the thermal conductivity and diffusivity around the fault zone.

High magnetic susceptibility has been observed in the black gouge in borehole B and black material (Hirono et al., 2006b). Mishima et al. (2006) conducted magnetic analysis on the ferrimagnetic minerals in FZB 1194 and FZB 1243 in more detail and concluded that the formation of magnetite or maghemite can be the cause of the high magnetic susceptibility in the fault core. They discussed that the ferrimagnetic minerals are formed by the thermal decomposition of inferrimagnetic minerals, such as siderites (Pan et al., 2000), lepidocrosite (Özdemir and Dunlop, 1993), or ferromagnetic iron sulfide (Snowball and Torii, 1999). They estimated the temperature to be at least $400^{\circ} \mathrm{C}$ on the basis of the thermomagnetic analysis.

On the other hand, Ohta and Yajima (1988) reported that the iron-rich chlorite is deposited at a higher temperature (approximately $200^{\circ} \mathrm{C}-450^{\circ} \mathrm{C}$ ) from ore deposit environments. Similarly, Vidal et al. (2006) also reported that the high iron content in chlorite at a higher temperature condition from the regional metamorphic belt although the condition of reaction can differ from the fault zones. In this study, the iron content in the chlorite is low in the fault core where a temperature rise is expected. Therefore, the temperature rise cannot explain the low value of the iron content in the chlorite.

Another factor that may control the iron content in the chlorite is a variation in the $\mathrm{pH}$ of fluid (Ross, 1969; Malmstrom, 1996). The $\mathrm{pH}$ of fluid can be changed by a radical reaction, which is an interaction between a surface that has been newly formed by fracturing and water (Kameda et al., 2003; Saruwatari et al., 2004). The gouge and breccia must be originated form the host rock of the Chinsui shale. The fractal distribution of the grain size in gouge suggested that the gouge is formed by brittle fracturing (Ma et al., 2006). It is difficult, however, to apply the experimental result of radical reaction to a natural example quantitatively because of the complexity of the mineral composition (Saruwatari et al., 2004).

The low values of iron contents in the chlorites are observed within the black gouge and black material at the center of the fault zone where magnetite or maghemite is supporsed to have formed (Mishima et al., 2006). The formation of iron oxide can be related to the low value of iron content in the chlorite at the fault core because the iron might be consumed by the formation of ferrimagnetic minerals. However, the temporal relationship between the formation of iron oxide and the low value of iron content in the chlorite is not clear so far.

In conclusion, the complex reactions are controlled not only by thermal decomposition but also by rock-fluid interaction. This is because the low value of the iron content in the chlorite is likely to be affected by the $\mathrm{pH}$ of fluid rather than the temperature raise at the seismogenic fault zones.

Edited by: J. Smit

\section{References}

Brown, G. and Brindley, G. W.: X-ray diffraction procedures for clay mineral identification, in: Crystal Structures of Clay Minerals and Thir X-Ray Identification, edited by: Brindley, G. W. and Brown, G., Monograph 5., Mineralogical Society, London, 305-359, 1980.

Hirono, T. Ikehara, M., Otsuki, K., Mishima, T., Sakaguchi, M., Soh, W., Omori, M., Lin, W., Yeh, E. C., Tanikawa, W., and Wang, C. Y.: Evidence of frictional melting from disk-shaped black material, discovered within the Taiwan Chelungpu fault system, Geophys. Res. Lett., 33, L19311, doi:10.1029/2006GL027329, 2006a.

Hirono, T., Lin, W., Yeh, E. C., Soh, W., Hashimoto, Y., Sone, H., Matsubayashi, O., Aoike, K., Ito, H., Kinoshita, M., Murayama, M., Song, S. R., Ma, K. F., Hung, J. H., Wang, C. Y., and Tsai, Y. B.: High magnetic susceptibility of fault gouge within Taiwan Chelungpu fault: Non-destructive continuous measurements of physical and chemical proper ties in fault rocks recovered from Hole B, TCDP, Geophys. Res. Lett., 33, L15303, doi:10.1029/2006GL026133, 2006b.

Kameda, J., Saruwatari, K., and Tanaka, H.: H2 generation in wet grinding of granite and single-crystal powders and implications for $\mathrm{H} 2$ concentration on active faults, Geophys. Res. Lett., 30, SDE 10-1-5, 2003.

Kano, Y., Mori, J., Fujio, R., Ito, H., Yanagidani, T., Nakao, S., and Ma, K.: Heat signature on the Chelungpu fault associated with the 1999 Chi-Chi, Taiwan earthquake, Geophys. Res. Lett., 33, L14306, doi:10.1029/2006GL026733, 2006. 
Ma, K. F., Brodsky, E. E., Mori, J., Ji, C., Song, T. R. A., and Kanamori, H.: Evidence for fault lubrication during the 1999 Chi-Chi, Taiwan, earthquake (Mw 7.6), Geophys. Res. Lett., 30, 48-1-4, 2000.

Ma, K. F., Tanaka, H., Song, S. R., Wang, C. Y., Hung, J. H., Tsai, Y. B., Mori, J., Song, Y. F., Yeh, E. C., Soh, W., Sone, H., Kuo, L. W., and Wu, H. Y.: Slip zone and energetics of a large earthquake from the Taiwan Chelungpu-fault Drilling Project, Nature, 444, 473-476, 2006.

Malmstrom, M., Banwar t, S., Lewenhagen, J., Duro, L., and Bruno, J.: The dissolution of biotite and chlorite at $25^{\circ} * \mathrm{C}$ in the nearneutral pH region, J. Contam. Hydrol., 21, 201-213, 1996.

Mishima, T., Hirono, T., Soh, W., and Song, S. R.: Thermal histor y estimation of the Taiwan Chelungpu fault using rock-magnetic methods, Geophys. Res. Lett., 33, L23311, doi:10.1029/2006GL028088, 2006.

Moore, D. M. and Reynolds, R. C.: X-ray diffraction and the identification and analysis of clay minerals, Oxford University Press, Wellington, 348, 1989.

Ohta, E. and Yajima, J.: Magnesium to iron ratio of chlorite as indicator of type of hydrothermal ore deposit, Mining Geology Special Issue, 12, 17-22, 1988.
Özdemir, Ö. and Dunlop, D. J.: Chemical remanent magnetization during $\gamma \mathrm{FeOOH}$ phase transformations, J. Geophys. Res., 98, 4191-4198, 1993.

Pan, Y. X., Zhu, R. X., Banerjee, S. K., Gill, J., and Williams, Q.: Rock magnetic properties related to thermal treatment of siderite: Behavior and inter pretation, J. Geophys. Res., 105, 783-794, 2000.

Ross, F. J.: Acid dissolution of chlorites: Release of magnesium, iron, and aluminum and mode of acid attack, Clay. Clay Miner., 17, 347-354, 1969.

Saruwatari, K., Kameda, J., and Tanaka, H.: Generation of hydrogen ions and hydrogen gas in quartz-water crushing experiments: An example of chemical processes in active faults, Phys. Chem. Miner., 31, 176-182, 2004.

Sibson, R. H.: Fault rocks and fault mechanisms, J. Geolog. Soc. London, 133, 190-213, 1977.

Snowball, I. and Torii, M.: Incidence and significance of magnetic iron sulphides in Quaternary sediments and soils, in: Quaternar y Climates, Environments, and Magnetism, edited by: Maher, B. A. and Thompson, R., pp. 199-230, Cambridge Univ. Press, New York, 1999.

Vrolijik, P. and van der Pluijm, B. A.: Clay gouge, J. Struct. Geol., 21, 1039-1048, 1999. 